\title{
Necessity and problems of formation of mechanisms of environmental and economic development of the regional industrial complex
}

\author{
Larisa Geieva ${ }^{1, *}$, Yaha Israilova ${ }^{1}$, Larisa Khatsieva $^{1}$, and Timur Yakubov ${ }^{1}$ \\ ${ }^{1}$ Grozny State Oil Technical University named after Academician MD, 100, Kh.A. Isaeva str., \\ Millionshchikov, Chechen Republic, Grozny, Russia
}

\begin{abstract}
The paper assesses the rationality of creating mechanisms for state regulation of investment activities at the level of regional government, in particular using the example of the Chechen Republic, as well as the dynamics of changes in the degree of attractiveness of the investment climate in the region, and the share of investments directed to environmental protection and rational use of natural resources. The need to form mechanisms of state regulation that ensure the sustainable development of industrial complexes on the territory of Russia and its regions, in particular the Chechen Republic, is currently based on the requirements of the Constitution of the Russian Federation.
\end{abstract}

\section{Introduction}

The need to form mechanisms of state regulation that ensure the sustainable development of industrial complexes on the territory of Russia and its regions, in particular the Chechen Republic, is currently based on the requirements of the Constitution of the Russian Federation, the Federal Law "On Environmental Protection" and other legislative acts regulating the list of issues of environmental protection, nature management and ensuring environmental safety for the population, Decrees of the President and Resolutions of the Government of the Russian Federation, as well as regulatory legal acts of the Administration of the Republic, tasks of the Strategic Development Plan of the Chechen Republic. In addition, this need is caused by the provisions set out in the Program of Action on Environmental Protection for Central and Eastern Europe, Agenda 21 and other documents of the UN Conference on Environment and Development, the Convention on the Protection of the Marine Environment of the Baltic Sea, as well as other international agreements. For example, at the World Summit on Sustainable Development (WSSD), held in August 2002 in Johannesburg (South Africa) under the auspices of the United Nations, with the participation of about 60 thousand delegates from 189 countries of the world, the goal to intensify the fight against hunger, poverty and environmental pollution on a planetary scale was proclaimed [1]. Ensuring sustainable development, as noted in the Agreement adopted by all countries participating in the summit, requires effective coordination (at the global and regional levels) between the relevant competent state bodies

* Corresponding author: salima@list.ru 
and organizations in the process of posing and solving problems at all levels of government, including the level of constituent entities. The agreement appeals to the governments of all countries to accelerate the ratification of the UN Convention on Sustainable Development, a step-by-step solution to the problem of reducing the level of environmental pollution.

In our opinion, the growing trend in international markets of focusing on the needs of the consumer, who is concerned about the problems of ecology, a healthy environment, and improving the quality of life, will also affect the Russian industry, where the influence and significance of the ecological characteristics of products, resource-saving and environmentally friendly technologies will increase. Whatever the strategic development of Russian industry, environmental factors as driving forces will become increasingly important when choosing priority areas and consumer markets. Therefore, the identification and solution of the main environmental and economic problems of the present and further development of industry as a whole and its individual enterprises is a necessary basis for the transition of industries to a sustainable development model and increasing its competitive potential in the national and international markets.

The system of scientific views, theory and methodological approaches to solving the problems of greening industrial production were formed over the past century in the works of such scientists as A.L. Bobrov, A.S. Grinin, E.M. Korotkov, E.I. Khabarova, T. Khusanova, A.Yu. Bezborodovykh, N.V. Pakhomova, A. Enders, K. Richter, Yu.V. Vabanina, S.S. Timofeeva. However, when defining environmentally oriented management in the works of these authors, only a part or one of the most essential part of this process is most often distinguished $[2,3]$.

Sometimes in the literature, there is an opinion about the essence of ecologized management as a process of managing the natural environment. However, firstly, the environment cannot be controlled. In our opinion, the processes of protection and use of natural resources are subject to management. Secondly, let us define the terminology, considering that the environment and the natural environment are synonyms, therefore, the use of the concept of "natural environment" in this work will be considered unscientific. Thirdly, the object of management is the processes occurring at an industrial enterprise that affect the state of the environment. The state of this environment depends on how comprehensively environmental goals are taken into account and implemented in solutions developed and implemented not only at the enterprise, but also in state bodies for control and regulation of investment and industrial activities. In this case, in our opinion, environmental management can act as a concept for building the entire management and investment activities of an industrial enterprise.

\section{Materials and Methods}

The research was carried out with the use of scientific methods of the analysis and synthesis, classification, mathematical statistics, economic analysis, mathematical modeling.

The materials for the research include the economic facts established on the basis of these statistical and financial and economic publications in Russia and other countries, data from Internet, materials of scientific seminars and conferences, statistical data of Goskomstat of the Russian Federation, data of the "New Economic Growth" agency, Russian Government Analytical Centre, National agency of financial studies. 


\section{Results and Discussion}

The formation of an environmentally oriented style of consumption of all types of resources, production of products, waste disposal, as well as the implementation of environmental protection plans are ensured not only by environmental management implemented at all levels of management - federal, regional, local, but also by environmental marketing. By this area of management, we mean the processes of development and implementation of the following green policies - production, distribution (sales), price and communication [5].

The integration of management mechanisms based on a systemic and integrated approach includes the following elements, which can be divided into three groups:

- the management process, which includes the tasks of setting goals (goal-setting), conducting an audit, forecasting, programming, monitoring, regulating investment projects, as well as motivating the active behavior of personnel in the process of environmentally oriented management;

- organizational, administrative (regulatory) and economic management mechanisms, which are institutional forms with the help of which the implementation of the developed investment policy and plans is ensured as an integral complex capable of not only ecological and economic survival, but also the development of an industrial enterprise;

- the process of implementing the investment policy and obtaining the results of the functioning of the organizational, administrative (regulatory) and economic mechanisms.

The concept of regulation of the investment activity of industrial enterprises allows a more complete presentation of environmental problems and methods of their solution in various areas of the industrial enterprise, including investment, belonging to the resource provision of production processes. In addition, this concept reflects the goals of sustainable development of industrial enterprises as elements of the industry in the short, medium and long term.

The industry of Russia is more dependent on investment resources than other sectors of the national economy, since it is based on fixed assets, which are distinguished by high cost. This specificity requires the development at the federal and territorial levels of management, the creation of a new concept for the formation of state industrial policy, including investment, as well as the creation of mechanisms for state regulation of investment activities that meet the goals of sustainable development of the entire national economy as a whole and its individual sectors, including industry [6].

So, for example, in 2019, a total of 117 million rubles were invested in environmental protection of the Chechen Republic. Almost all investments were directed to the protection and rational use of land $-99.6 \%$. [7]

Table 1. Fixed capital investments aimed at environmental protection and rational use of natural resources*.

\begin{tabular}{|l|c|c|c|c|c|c|c|c|c|}
\hline & $\mathbf{2 0 1 0}$ & $\mathbf{2 0 1 3}$ & $\mathbf{2 0 1 4}$ & $\mathbf{2 0 1 5}$ & $\mathbf{2 0 1 6}$ & $\mathbf{2 0 1 7}$ & $\mathbf{2 0 1 8}$ & $\mathbf{2 0 1 9}$ \\
\hline \multicolumn{7}{|c|}{ Million rubles } \\
\hline Fixed capital investments - total & 76.5 & 0.5 & 209.2 & 576.6 & 531.2 & 94.3 & 716.2 & 117.0 \\
\hline including: & & & & & & & & \\
\hline for protection and rational use of & & & & & & & & \\
\hline water resources & 71.6 & 0.1 & 0.7 & 368.7 & 452.0 & - & 683.4 & 0.1 \\
\hline $\begin{array}{l}\text { for the protection of atmospheric } \\
\text { air }\end{array}$ & 0.1 & 0.4 & 0.4 & 0.4 & 0.3 & 0.4 & 0.5 & 0.2 \\
\hline for protection and rational use of & & & & & & & & \\
\hline land & 4.8 & - & 204.5 & 207.5 & 78.8 & 93.9 & 32.4 & 116.7 \\
\hline other measures & - & - & 3.6 & - & 0.1 & - & - & - \\
\hline As a percentage of the previous year (in comparable prices) \\
\hline
\end{tabular}




\begin{tabular}{|l|c|c|c|c|c|c|c|c|}
\hline Fixed capital investments - total & 34.2 & 0.2 & $\begin{array}{c}413 \\
\text { tim. }\end{array}$ & $\begin{array}{c}2.6 \\
\text { tim. }\end{array}$ & 89.6 & 17.3 & $\begin{array}{c}6.5 \\
\text { tim. }\end{array}$ & 16.3 \\
\hline including: & & & & & & & & \\
\hline for protection and rational use of & & & & & & & & \\
\hline water resources & 48.6 & $\mathrm{x}$ & $\begin{array}{c}6.9 \\
\text { tim. }\end{array}$ & $\begin{array}{c}500 \\
\text { tim. }\end{array}$ & 119.2 & $\mathrm{x}$ & $\mathrm{x}$ & 0.0 \\
\hline $\begin{array}{l}\text { for the protection of atmospheric } \\
\text { air }\end{array}$ & 92.7 & 48.6 & 98.8 & 95.0 & 72.9 & 129.6 & 107.2 & 40.0 \\
\hline for protection and rational use of & & & & & & & & \\
\hline land & 6.3 & - & $\mathrm{x}$ & 96.4 & 36.9 & 115.8 & 29.6 & $\begin{array}{c}3.6 \\
\text { tim. }\end{array}$ \\
\hline other measures & - & - & $\mathrm{x}$ & - & $\mathrm{x}$ & - & - & - \\
\hline
\end{tabular}

${ }^{*}$ Without small businesses and the volume of investments that are not observed by direct statistical methods.

Simultaneously with the increase in the importance of state mechanisms for regulating investment activities aimed at ensuring the study, protection, reproduction and regulation of the use of natural resources, the responsibility of industrial enterprises in the process of solving sustainable development problems in such processes as resource consumption, production, sales, and waste disposal is increasing. This is caused by the fact that in transitive conditions, many tasks of sustainable development were previously solved at the sectoral level of management, and now it is necessary to solve them at the local level of an economic entity - an industrial enterprise. The reasons for this may be the increased number of business entities, belonging to various forms of ownership, weakening of the state vertical of management and control over production processes, the change in the organizational structure of the industrial complex, and the strengthening of the greening of public opinion.

The concept of ecologized management as one of the forms of the enterprise's relationship with the environment is now becoming more widespread in the domestic scientific literature [8-11]. However, in the scientific literature, environmental protection is identified with ecology, and the concept of "ecological" is considered as not causing harm to the environment. In our opinion, ecology is a science that studies the interaction of man, economic, social, technical and other systems with the natural environment, and the concept of ecological is broader, implying protection, restoration, rational, sustainable, balanced use of natural resources, and environmentally oriented management - it is the concept of building the entire management system, taking into account the problems of environmental protection in the processes of interaction with the external marketing environment at the macro and micro levels.

So, the external environment of the macro level includes such environments as: political, which determines the legal framework for the functioning of both industrial enterprises themselves, and for the operation of the state mechanism of control and regulation of environmental, investment and other types of activities; economic, including the norms and standards of payment for the use of natural resources, pollution of the natural environment; demographic environment characterized by the level of morbidity of the population, life expectancy; cultural, reflecting the level of environmental awareness of the population, mass media, government bodies, civil society; scientific and technical, including new/innovative materials that replace natural resources, low-waste, environmentally friendly production technologies, disposal of used products, waste; natural environment characterized by the state of all its components - the atmosphere, hydrosphere, lithosphere, flora, fauna, soil, land and waste - on the territory of the whole country and its regions.

At the micro level, the external marketing environment of an industrial enterprise includes suppliers of all types of resources necessary for the implementation of production 
processes - material, including natural and energy, information, labor, financial, including investment, fixed assets / real estate. Ecologization of management in this case focuses on the use of such resources, which can be called environmentally friendly, low waste, environmentally prepared, environmentally oriented.

In addition to micro-level suppliers, competitors, intermediaries, customer markets and contact audiences interact with the environment. Therefore, environmentally oriented management positions the products of its enterprise with the products of competitors, which can be comparable in terms of the degree of greening the processes of resource use, production and waste disposal. In our opinion, in a transitional economy, the foundations are laid for the formation of the image of industrial enterprises, reflecting a certain degree of greening of products, production processes, protection and pollution of the environment.

Marketing intermediaries, who provide the processes of commodity circulation, commodity promotion, sales and insurance of purchase and sale transactions, also participate in the process of interaction with the environment, and the choice of intermediaries also reflects the degree of greening of the entire management system.

Clientele markets, including consumers of industrial products in the form of households, manufacturers of products based on manufactured goods, intermediate sellers and also state and municipal bodies, international markets, according to the author, influence the degree of use of industrial products, their utilization and the volume of waste generation.

The industrial enterprise management system should cooperate only with those elements of the external marketing environment of the micro level, which, like this system, share the concept of environmental orientation [12].

Thus, the concept of ecological orientation is aimed at creating processes of interaction and relationships of an industrial enterprise not only with the environment, arising in the course of production and rendering of services, but also with elements of the external marketing environment at the macro and micro levels [13-15]. Thus, we can say about the creation of an environmentally oriented interaction of the elements of market relations in transitive conditions on the territory of Russia as a whole and its regions in the form of separate entities.

Ultimately, the goal of greening management is to minimize the overall, integrated negative impacts of all activities of an industrial enterprise on the environment, both directly and indirectly, through other elements of market relations, reducing the level of resource consumption, achieving a high degree of environmental safety in the production and consumption of goods. However, the goal of greening is not the main strategic goal in transitive conditions, as mentioned above. This goal serves as one of the necessary conditions for such a goal as ensuring competitive advantages in the selected target markets - territorial, demographic, and others, for example, the markets of state and municipal bodies.

Environmentally oriented management as a concept for creating the entire management system of an industrial enterprise realizes the goal of creating and maintaining the competitiveness of an industrial enterprise, set by the environmental aspects of its activities in modern conditions [16-20].

According to the author, the basis of an environmentally oriented management system for an industrial enterprise should be an investment strategy that allows ensuring the complementarity of environmental and socio-economic goals not only for the enterprise, but also the formation of appropriate environmental and economic conditions for society at the micro level - district, municipal, city. A modern industrial enterprise is the main subject, within the boundaries of which the main tasks of the investment strategy are solved: the rational use of natural resources, ensuring the environmental safety of the population, improving the quality of life of the team. 


\section{Conclusions}

Summing up all of the above, we can state that the concept of sustainability finds its interpretation in the theory of transaction costs and influences the development of mechanisms of state control and regulation of investment activity in the process of solving the following problems.

The first problem of investing in environmentally efficient projects is that there is a strong opinion about the prevailing value of production costs, the optimization or reduction of which is the main task of the management system, and all other areas of management activity, except for production processes, are of secondary importance and can be solved in second, third or other place. From the point of view of the prevalence of the importance of the production process and the need for its analysis and optimization, the required volume of production and the specified profit, including the maximum one, are provided.

All other processes, including the processes of resource provision, as well as investment, are "perfect", as well as the sales processes are not subject to further improvement. All disturbing influences from the elements of the external marketing environment at the macro and micro levels are regarded as insignificant and do not have an irrational effect on the development of the production process. Consequently, the main use of investments is only production processes.

The second problem is the need to foresee and plan the time and costs for the period of adaptation of processes, mainly production and investment ones, to the changing conditions of the external environment, which is not static. The stochasticity of the external environment is manifested in the change in prices for resources, finished products, the interest rate fluctuates, and there is a deviation of the investor's behavior from the expected and planned in advance. Under the influence of these variables, which should be considered as exogenous uncontrollable, production and investment processes should move to a new equilibrium state. To achieve such a new state, time and costs are required for adaptation, manifested in the need to adapt the fixed assets of the enterprise, the acquisition of new or more expensive materials and personnel. There is a restructuring of processes from one equilibrium state to another. The integration of adaptation costs increases the amount of required investment.

The third problem is the need to form adequate information support and plan costs for obtaining information resources that reflect changes in the external environment. The problem of lack of the necessary information leads to the need for additional time and, consequently, cost expenditures for coordinating the activities of production units in the presence of imperfect, incomplete information. The increase in the cost of performing the coordination function leads to a corresponding increase in costs and a decrease in profits.

The fourth problem is a consequence of the previous one and consists in the need to plan the costs of carrying out control and regulation functions at various levels of government. The information problem increases even more if there is a discrepancy, inconsistency in the goals of activity between the industrial enterprise as a whole and its team, between various structural divisions (departments, services), individual team members, managers of various levels - higher, middle and lower - linear. The difference in such goals is caused by the differentiation of interests, to which, according to the theory of principal-agents, the difference in goals and interests between owners and hired managers belongs. Theoretically, the criterion for the selection of management decisions, including investment environmental ones, in the process of searching and selecting information should be the dynamics of profit, its undoubted growth. However, in practice, information, including unreliable, incorrect information can be selected and entered in such a way as to ensure lobbying and further implementation of the individual goals of individual managers, 
employees, or group goals of departments, services, divisions. This situation calls for the improvement of control and regulation functions.

The fifth problem of transaction costs is caused by the need to coordinate relations of an industrial enterprise (transactions) with consumers and suppliers of raw materials, intermediaries, the public, government control and regulation bodies. These relations are accompanied by significant costs, which have a greater impact on the adoption of investment decisions, on the formation of optimal production relations in transitive conditions than in stable ones.

The sixth problem of integration means the need to anticipate the costs of logistics processes. It is practically caused by the fact that effective transactions can be regulated at any level of government, not only with the help of appropriate agreements. Industrial enterprises practically exchange not just the results of their activities, exchanging goods for money in the process of a transaction, but jointly create the final results themselves. Especially such trends are manifested in the context of horizontal integration of industrial enterprises, since integrated processes require mutual structural coordination of supply, production, sales, market research, the structure of management systems and the structure of the general proposal of the result of the activities of all business partners. In this case, the general goal of integration is to minimize / optimize emerging integration costs. However, the introduction of such integration costs into investment plans is necessary.

The seventh problem - environmental problem. It is manifested in the need to increase the cost of purchasing natural environmentally friendly resources and reduce the level of environmental pollution. Transactions between an industrial enterprise and the environment can only be regulated on the basis of contracts and cooperation as long as there is an identified contractual partner. The assumption that existed at the beginning of the transition period that the consumption of resources and the volume of products produced by an industrial enterprise are regulated by spontaneous market relations under the influence of supply and demand in the markets for raw materials and goods is incorrect. Increasingly, the situation is manifested when the natural environment is no longer a supplier of free goods. On the contrary, there are significant costs for the extraction and supply of these benefits, the preservation and protection of the natural environment, which previously could not be taken into account when assessing investment projects.

\section{References}

1. The concept of sustainable development and Local agenda for the XXI century: a methodological guide (SPb, publishing house "Union of Artists", 2003)

2. N. Pakhomova, K. Richter, A. Enders, Environmental management. Workshop (SPb, Piter, 2004)

3. Environmental policy: foundations, levels, implementation methodology (M., Publishing house of RAGS, 2004)

4. A.G. Aganbegyan, Socio-economic development of Russia (M., Delo, 2004)

5. M. Porter, Competition (SPb, Piter, 2000)

6. I.P. Bogomolova, N.V. Shishkina, A.N. Karaichev, Strategic management of the development of a large industrial enterprise (Voronezh, Istoki, 2004)

7. Main socio-economic characteristics of the Chechen Republic 2020, https://chechenstat.gks.ru/storage/mediabank/8AFwPjLd/\%D0\%95\%D0\%96\%D0\%95 \%D0\%93\%D0\%9E\%D0\%94\%D0\%9D\%D0\%98\%D0\%9A\%20\%202020.pdf

8. A.G. Ananenkov, G.P. Stavkin, O.P. Andreev, I.L. Khabibullin, S.A. Lobastova, Ecological and economic management of environmental protection (M., LLC "Nedra- 
Business Center", 2003)

9. M. Nechaeva,, V. Nechaev, A. Mottaeva, E3S Web of Conferences 258, 03011 (2021) https://doi.org/10.1051/e3sconf/202125803011

10. A.A. Gusev, Regional environmental policy of Russia (M., Institute of Comparative Political Science of the Russian Academy of Sciences, 2003)

11. Modeling the socio-ecological-economic system of the region (M., Nauka, 2003)

12. A.I. Dolotov, Study of the influence of the "external environment" in the strategic management of corporations (Perm, 2004)

13. M.S. Santalova, State economic policy: theory, methodology and practice (Voronezh, Voronezh State University, 2004)

14. E. Eliseeva, A. Mottaeva, E3S Web of Conferences 244, 10028 (2021) https://doi.org/10.1051/e3sconf/202124410028

15. Environmental policy: foundations, levels, implementation methodology (M., Publishing house of RAGS, 2004)

16. A. Gurtuev, E. Derkach, S. Makhosheva, Z. Ivanov, Heliyon 6(11) (2020)

17. S.A. Tumenova, M.M. Kandrokova, S.A. Makhosheva et al., Espacios 39(26) (2018)

18. S.A. Makhosheva, N.Y. Rud, M.M. Kandrokova, M.V. Israilov, F.B. Shinahova, Espacios 39(47) (2018)

19. A.B. Mottaeva, A.B. Mottaeva, International Journal of Applied Engineering Research 10(23), 43446-434499 (2015)

20. A. Mottaeva, J. Stepanova, N. Meshkova, G. Semenova, European Journal of Sustainable Development 109(1), 705-723 (2021) Doi: 10.14207/ejsd.2021.v10n1p705 